\title{
THE FUNDAMENTAL RETROSPECTIVE ANALYSIS OF PHARMACY HUMAN RESOURCES IN UKRAINE FOR 1981-1990
}

\author{
M.S.Ponomarenko, O.S.Solovyov, S.V.Augunas, Yu.M.Grygoruk \\ National Medical Academy of Postgraduate Education (NMAPE) named after P.L.Shupyk \\ Vinnytsya National Pirogov Memorial Medical University
}

Key words: pharmaceutical personnel; distribution; statistics; ratio of the personnel groups

The modern concept of development of pharmaceutical industry in Ukraine requires knowledge of its historical development, including the elements of the optimal use of pharmacy human resources (PHR), implementation and adaptation of its work associated with introduction of family, insurance medicine, the use of the positive experience of the previous years. The fundamental retrospective analysis of PHR of Ukraine for 1981-1990 has been conducted. The data are presented for consideration of the positive (negative) experience of pharmacy and comparison with modern requirements of the pharmaceutical branch.

Pharmaceutical system with its subsystems, components and elements of separate organizational management segments, including human resources, was and remains an integral part of the concept of the healthcare system development in Ukraine. The modern concept of development of pharmaceutical industry in Ukraine requires knowledge of its historical development, including the elements of the optimal use of pharmacy human resources (PHR), implementation and adaptation of its work associated with introduction of family, insurance medicine, the use of the positive experience of the previous years [1-16].

In the works by I.M.Gubskiy, M.V.Slabyi it was noted that the system analytical information regarding a comprehensive study of the pharmaceutical staff training and distribution of pharmaceutists and pharmacists, as well as determination of their needs over the previous years was almost absent. Since independence of Ukraine exactly the comprehensive analysis of distribution of these professionals was carried out only as of 01.01 .1993 [1, 6-8]. However, the multidimensional studies of educational training, the condition and the process of functioning of the pharmacy personnel in Ukraine were conducted by I.M.Gubskiy, D.S.Volokh, O.L.Hrom, O.M.Zalis'ka, A.A.Kotvitska, T.M.Krasnyanska, Z.M.Mnushko, A.S.Nemchenko, B.L.Parnovskiy, R.M.Pinyazhko, M.S.Ponomarenko, M.V.Slabyi, M.L.Syatynya, V.M.Tolochko, V.P.Chernykh and some other researchers. They highlighted many valuable points of the staffing history and the theory of training, as well as formation of the personnel potential of Ukraine. However, these studies require prolongation in order to solve current innovative problems of education and retraining, improvement of the personnel, appropriate legislation and implementation regulations according to the EU requirements.

The aim of the work was to conduct the retrospective analysis of PHR in Ukraine in the period from 1981 to 1990. Carrying out this study will allow to actuate fur- ther the provisions of Good Pharmacy Practice (GPP) $[3,4]$, as well as implement other European experience in pharmacy [9-16].

\section{Materials and Methods}

The study subject was retrospective historical literary sources, official analytical report of the Main Department of Pharmacy of the Ministry of Public Health of Ukraine. The basic methodological strategy of the study were the methods of historical research, hierarchical, facet, empirical, statistical, graphologic and other methods of evidence-based pharmacy.

\section{Results and Discussion}

The previous studies showed the available information concerning the start of distribution of the pharmaceutical staff in the pharmacy chain for 1913-1940. The analysis of the staff composition of pharmacy employees during the period of 1950-1980 was also carried out. The data of the fundamental statistical retrospective analysis of PHR of Ukraine (pharmacy employees of the retail chain as of 01.01. 1981-1990) are presented in Table.

As evidenced by the data, in the period of 1981-1990 there was a stable (planned) ratio of pharmacists and pharmaceutists. The average index of the pharmacist : pharmaceutist ratio for the period studied was 1.4 (1.36). The analytical chart of the retrospective analysis of pharmacy human resources for the period specified (Fig.) shows that the total number of pharmacy employees increased by $128.6 \%$ within 10 years, including pharmaceutists and pharmacists - by $123.4 \%$ and $109.9 \%$, respectively (together in the amount - by $115.5 \%$ ).

It should be noted that in 1972 short-term annual training cycles for probationers in medicine and pharmacy were opened. Of 266 probationers 153 people occupied positions of pharmacists in pharmacies of Ukraine in 1981. Moreover, their greatest number was observed in pharmacies of Dnipropetrovsk - 48; Kharkiv - 38; Donetsk - 30 and Kyiv - 10. On average, in Ukraine, the staff sufficiency in pharmacy in 1981 was 7.5 persons 
Table

The fundamental retrospective analysis of pharmacy human resources of Ukraine (pharmacy employees of the retail chain as of 01.01.1981-1990)

\begin{tabular}{|c|c|c|c|c|c|}
\hline \multirow[b]{2}{*}{ Years } & \multirow[b]{2}{*}{$\begin{array}{l}\text { The number of } \\
\text { people working in } \\
\text { the pharmacy chain }\end{array}$} & \multicolumn{3}{|c|}{ Pharmacy human resources } & \multirow[b]{2}{*}{$\begin{array}{l}\text { The pharmacist : } \\
\text { pharmaceutist ratio }\end{array}$} \\
\hline & & pharmaceutists & pharmacists & $\begin{array}{c}\text { In all: } \\
\text { pharmaceutists } \\
\text { and pharmacists }\end{array}$ & \\
\hline 1981 & 62790 & 15401 & 22049 & 37450 & 1.43 \\
\hline 1982 & 63616 & 15941 & 22524 & 38465 & 1.41 \\
\hline 1983 & 64664 & 16336 & 23157 & 39493 & 1.42 \\
\hline 1984 & 65726 & 16650 & 23314 & 39964 & 1.40 \\
\hline 1985 & 67199 & 17059 & 23863 & 40922 & 1.40 \\
\hline 1986 & 68181 & 17548 & 24013 & 41561 & 1.37 \\
\hline 1987 & 68644 & 18008 & 23930 & 41938 & 1.33 \\
\hline 1988 & 69431 & 17008 & 22535 & 39543 & 1.32 \\
\hline 1989 & 69449 & 17236 & 22658 & 39894 & 1.31 \\
\hline 1990 & 80726 & 19012 & 24229 & 43241 & 1.27 \\
\hline Average indices & 68042 & 17020 & 23227 & 40247 & 1.36 \\
\hline
\end{tabular}

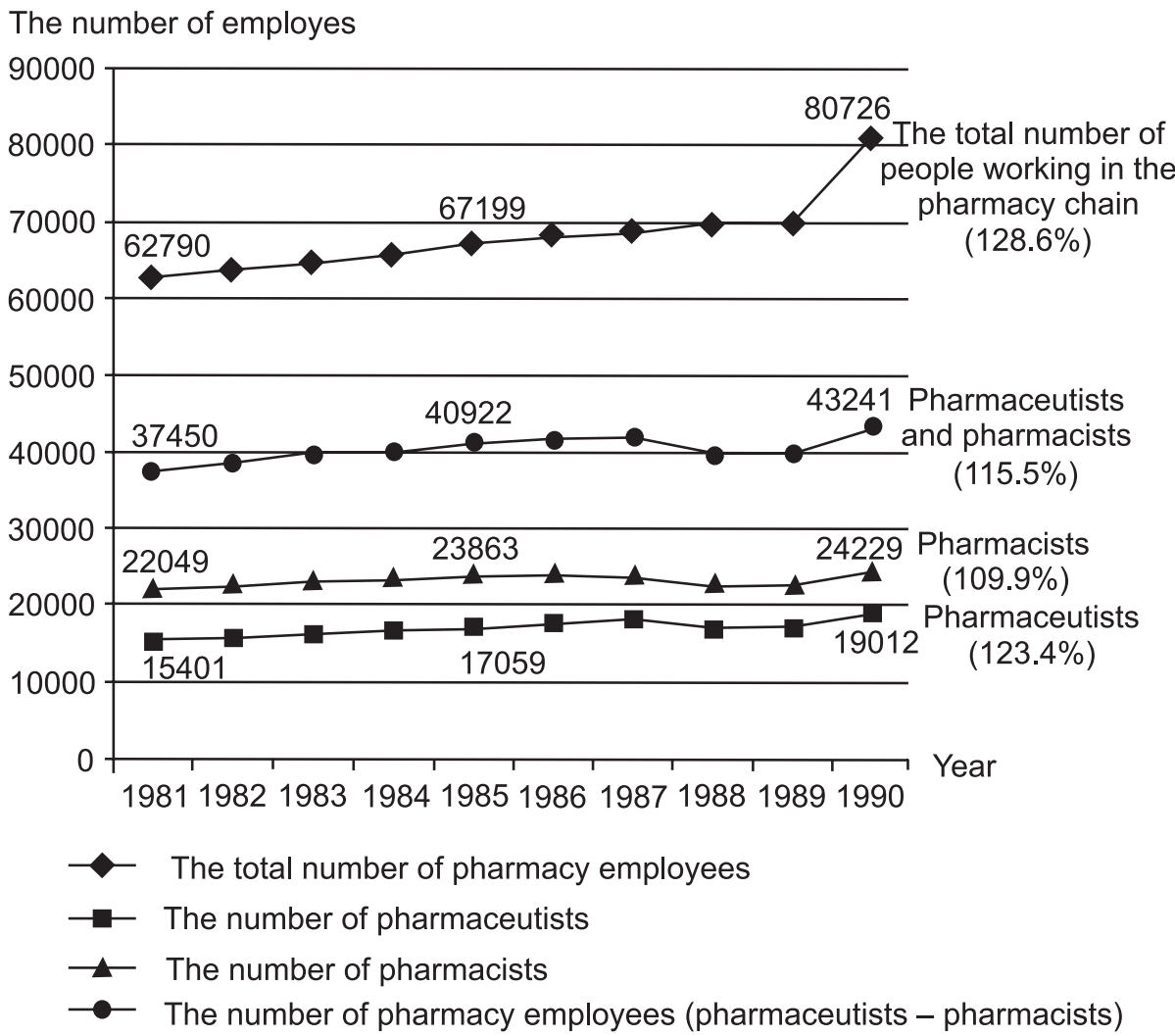

Fig. The analytical chart of retrospective analysis of PHR for 1981-1990.

per 10 thousand population; it exceeded the level of 1980 by 0.3 persons. The number of the population (inhabitants) per 1 pharmacy in 1981-1982 was overall 8.5 thousand (9.5 in cities and urban-type settlements and 7.1 thousand in rural areas).

The professional staff sufficiency in pharmacy increased during the period studied, and, for example, in 1988 it was 8.3 persons per 10 thousand population, including pharmaceutists -3.6 and pharmacists -4.7 . In 1988 institutions and enterprises of the pharmaceutical industry of Ukraine were staffed in general by $95.2 \%$. Undermanning was 1285 pharmaceutists and 878 pharmacists.

\section{CONCLUSIONS}

The fundamental retrospective analysis of pharmacy human resources of Ukraine for 1981-1990 has been conducted. The data are presented for consideration of the positive (negative) experience of pharmacy and comparison with modern requirements of the pharmaceutical branch. 


\section{REFERENCES}

1. Губский И.М., Бушкова М.Н., Яковец Н.И. Аптечное дело в Украинской ССР. - Чернигов: Облтипография, 1958. -207 c.

2. Инструктивные материаль по анализу показателей деятельности аптечных управлений Украинской ССР за 1981-1990 г2. / Д.С.Волох, М.С.Родина // Областное аптечное управление лаборатория НОТ и управления. - К., 1981. - 123 с.; 1982. - 143 с.; 1983. - 140 c.; 1984. - 146 c.; 1985. - 139 c.; $1986 .-170$ c.; 1987. - 87 c.; 1988. - 106 c.; 1989. - 115 c.; 1990. - 131 c.; 1991. - 169 c.

3. Надлежащая аптечная практика в новых независимых государствах [Електронний ресурс]. - Режим docmyny: http://www.apteka.ua/article/ 13215, http://www.apteka.ua/article/13233, http://www.apteka.ua/ article/13254, http://www.apteka.ua/article/13291

4. Мурашко А.М., Левашова О.Л. Належна аптечна практика // Фармацевтична енциклопедія. Гол. ред. ради В.П. Черних. - 2-ге вид., перероб. і доп. - К.: МОРІОН, 2010. - 956 с.

5. Правові системи сучасності: Навч. посіб. / Відп. ред. Ю.С.Шемчуженко. - К.: Вид-во «Юридична думка», 2012. - 492 c.

6. Слабий М.В. Аналіз стану та шляхи оптимізації системи фармацевтичних кадрів в Україні: Автореф. дис. ... докт. фармац. наук. - Львів, 2010. - 46 с.

7. Слабий М.В., Парновський Б.Л., Заліська О.М. // Фармац.. журн. - 2005. - №2. - С. 34-38.

8. Слабий М.В., Парновський Б.Л., Заліська О.М. // Фармац. журн. - 2006. - №1. - С. 29-33.

9. Хронометричний аналіз незавериених законотворчих інічіатив з фармащевтичного права / М.С.Пономаренко, О.С.Соловйов, Ю.М.Григорук // Матер. III Всеукр. науково-освітн. Internet-конференції: «Формування національної лікарської політики за умов впровадження медичного страхування: питання освіти, теорї та практики». - Харків, 12 березня 2015 року. - Х.: НФаУ, 2015. - C. 28-39.

10. Paun C. Between Collaboration and Competition. Global Public-Private Partnerships against Intellectual Property Crimes // TranState Working Papers №149. - Bremen, 2011. - 30 p.

11. Pharmaceutical Crime [Eлектронний ресурс] / Interpol. - Pежим достуny: http://www.interpol.int/Crimeareas/Pharmaceutical-crime/Pharma-ceutical-crime

12. PPRI Glossary [Cited 2010, 13 Jan.]. - Available from: http://ppri.oebig.at/index.aspx?Navigation=r|4-

13. Ravinetto R.M., Bolaert M., Jacobs J. et al. // Tropical Medicine \& International Health. - 2012. - Vol. 17, Issue 11. - P. 1412-1416.

14. Regulating pharmaceutical in Europe: striving for efficiency, equity and quality. - Open 11. University Press, 2004. -394 p.

15. Report on the proposal for a directive of the European Parliament and of the Councilamending Directive 2001/83/EC as regagds the prevention of the entry in to the legal supply chain of medicinal products which are falsified in relation to their identity, history and sourse. Session document. A7-0148/2010 dated 7.5.2000 [Електронний ресурс] / EuropeanParliament:Committee of the Environment, Public Health and Food SafetyPежим доcmyny: http://www.europarl. europa.eu/sides/getDoc.do? pubRef=-//EP//NONSGML +REPERT +A72010-0148+0+DOC $+P D F+V 0 / / E N \&$ language $=E N$

16. Zanzibar Declaration on Counterfeit Medical Products and Pharmaceutical Crime: dated 2 September 2010. [Електронний ресурс]. - Режим достуnу: http://www.interpol.int/Media/Files/Crime-areas/Pharmaceuticalcrime/Resources/The-Zanzibar-Declaration-on-Counterfeit-Medical-Products-and-Pharmaceutical-CrimeSigned-in-September-2010-following-the-conclusion-of-Operation-Mamba-III-Eastern-Africa

\section{ПОГЛИБЛЕНИЙ РЕТРОСПЕКТИВНИЙ АНАЛІЗ ФАРМАЦЕВТИЧНИХ КАДРОВИХ РЕСУРСІВ} В УКРАЇНІ ЗА 1981-1990 pp.

М.С.Пономаренко, О.С.Соловйов, С.В.Аугунас, Ю.М.Григорук

Ключові слова: фрармацевтичні кадри; розподіл; статистика; співвідношення кадрових угрупувань

Сучасна концепція розвитку фрармацевтичної галузі України потребує знання їі історичного становлення, в тому числі й засад оптимального використання фрармацевтичного кадрового потенціалу, втілення та адаптації його роботи, пов'язаної з запровадженням сімейної і страхової медицини, використання позитивного досвіду попередніх років. Проведено поглиблений ретроспективний аналіз кадрового складу аптечних закладів України за 1981-1990 рр. Дані представлені для урахування позитивного (негативного) досвіду аптечної справи та порівняння з сучасними вимогами до фрармацевтичної галузі. 


\section{УГЛУБЛЕННЫЙ РЕТРОСПЕКТИВНЫЙ АНАЛИЗ ФАРМАЦЕВТИЧЕСКИХ КАДРОВЫХ}

\section{РЕСУРСОВ В УКРАИНЕ ЗА 1981-1990 гr.}

Н.С.Пономаренко, А.С.Соловьев, С. В.Аугунас, Ю.Н.Григорук

Ключевые слова: фрармацевтические кадры; распределение; статистика; соотношение кадровых группировок

Современная концепция развития фрармацевтической отрасли Украины требует знания ее исторического становления, в том числе оптимального использования фрармацевтического кадрового потенциала, адаптации его работы, связанной с внедрением семейной и страховой медицины, использования положительного опыта предыдущих лет. Проведен углубленный ретроспективный анализ кадрового состава аптечных учреждений Украины за 1981-1990 га. Данные представлены для использования положительного (отрицательного) опыта аптечного дела и сравнения с современными требованиями к фармацевтической отрасли. 